\title{
The Level of Energy Poverty in Poland Compared to other European Union Countries
}

\section{Arkadiusz PIWOWAR}

Wroclaw University of Economics and Business, Wrocław, Poland, arkadiusz.piwowar@ue.wroc.pl

\begin{abstract}
Energy poverty that affects households is an adverse economic phenomenon with negative economic, social and environmental consequences. This paper presents a comparative analysis of indicators characterizing energy poverty in Poland and other European Union countries. Data from the Eurostat database were used for this purpose. The time range of the analysis covered the period of 2009-2018. As it results from the analyses, Poland is one of the countries where the situation related to the households (with income below $60 \%$ of the median income) declaring the inability to keep home adequately warm significantly improved in the investigated period. The average level of this indicator in the EU in 2018 was 7.3\%. Against this background, the current level of the discussed indicator in Poland is favourable (in 2018 in Poland the value of the indicator was 5.1\%). The findings may be important from the point of view of shaping public policy aimed at reducing the phenomenon of energy poverty in Poland.
\end{abstract}

Keywords: energy poverty; expenditures on energy; energy needs; family economics; Poland

JEL Classification: I32; Q41; G50

\section{Introduction}

Energy poverty is a term used when households suffer from insufficient funds for covering their basic energy needs (Castaño-Rosa et al., 2019; Primc \& Slabe-Erker, 2020). According to the IAE (International Energy Agency), it is estimated that 1.3-2.6 billion people in the world experience energy poverty (Doukas \& Marinakis, 2020). A large part of the population in the rural regions of Sub-Saharan Africa and the India subcontinent lives without access to electricity (Samarakoon, 2019; Gupta et al., 2020). The problem of energy poverty occurs also in Asia (inter alia in Cambodia) (Khanna et al., 2019). Energy poverty has to be understood in the context of social, physical, psychological and technological conditions (Libor \& Bouzarovski, 2018). In the literature on the subject, the relationships between energy poverty and the issues of socio-economic development are emphasized (Wei et al., 2018). This problem does not only concern countries with a relatively underdeveloped economy, but also countries with stable foundations and a relatively stable macroeconomic situation. While in countries located in Africa the problem is, among other things, low energy generation capacity and infrastructure for the electricity distribution, in Europe this problem is related primarily to energy purchasing costs (Monyei et al., 2018; Olang et al., 2018). As mentioned earlier, the problem of energy poverty, a serious social issue, affects many European countries (Mayer et al., 2018; Boemi \& Papadopoulos, 2019; Dobbins et al., 2019). In southern European countries, this problem exists too - despite mild winters, many people do not satisfy their 
energy needs in terms of thermal comfort at home (Castaño-Rosa et al., 2020a; Gouveia et al., 2018; Betto et al., 2020). Despite a favourable (mild) climate, also Portugal is considered one of the most vulnerable countries in the European Union in terms of energy poverty (Horta et al., 2019). The economic and social consequences associated with energy poverty are also addressed in Latin American countries (Pablo et al., 2019).

The problem raised in this study is more and more broadly discussed and studied, although it is not yet recognized fully both in the European Union and in individual countries. This applies not only to empirical research, but also to the legal bases in the investigated scope (Mędrzycki \& Szyrski, 2018; Sareen et al., 2020). Financial conditions (economic poverty) and a low level of energy efficiency of buildings are at the root of the problem of energy poverty. The energy consumption is also by occupants' behaviour causing pre- or re-bound effects (Calì et al., 2016). Measuring energy poverty is difficult, as there are many elements that have a real, direct and indirect impact on the phenomenon under study (Thomson et al., 2017). The purpose of this study is to show changes in energy poverty in Poland as compared with other European Union countries. To analyze energy poverty, it is necessary to develop the state of the matter from an international perspective (Castaño Rosa et al., 2020b). In addition, expenses on the purchase of energy in Polish households were presented, based on statistical data. Economic categories (i.e. incomes and expenses) were used to analyse and evaluate this situation.

\section{Methodology}

In the literature on the subject, there are many indicators for measuring energy poverty. There can be distinguished objective and subjective indicators, based on the feelings of residents (Romero et al., 2018). The basic indicator for assessing the extent of the problem of energy poverty is the percentage of households (with an income below $60 \%$ of the median income) declaring the inability to keep home adequately warm. Further in the paper, the situation in Poland was compared with the other EU-28 countries, based on this indicator. The analysis carried out is of relative nature. The main time range of the analyses covered the period of 2009-2018. The numerical data were taken from the Eurostat database and official statistics in Poland.

\section{Results and Discussion}

In Europe, the issue of energy poverty is particularly important in countries of Central and Eastern Europe, which is associated with a relatively low income of residents of this area in comparison with Western European countries as well as with natural conditions and their consequences in the area of energy management (relatively high amplitude of temperature fluctuations during the year, length of the heating season, etc.) (Streimikiene \& Balezentis, 2019; Druică et al., 2019; Tsanov \& Shopov, 2018). Central and Eastern European countries are characterized by a relatively low share of energy expenses in the household expenses in the EU (Figure 1). Encumbrance with energy expenditures in this part of Europe is lower than in other EU countries (an exception is the Czech Republic). 
Eurostat data for 2017 show that $19.5 \%$ of the population in Poland was at risk of poverty and social exclusion. On the EU scale, this placed Poland on the 12th position among all EU-28 countries - counting from the country with the lowest scale of this problem. In 2018, households in the European Union (EU) spent over 2,065,042.3 million Euro (current prices) on "housing, water, electricity, gas and other fuels". Share of housing, water, electricity, gas and other fuels in total household expenditure in the EU Member States in 2017 and 2018 are shown in Figure 1.

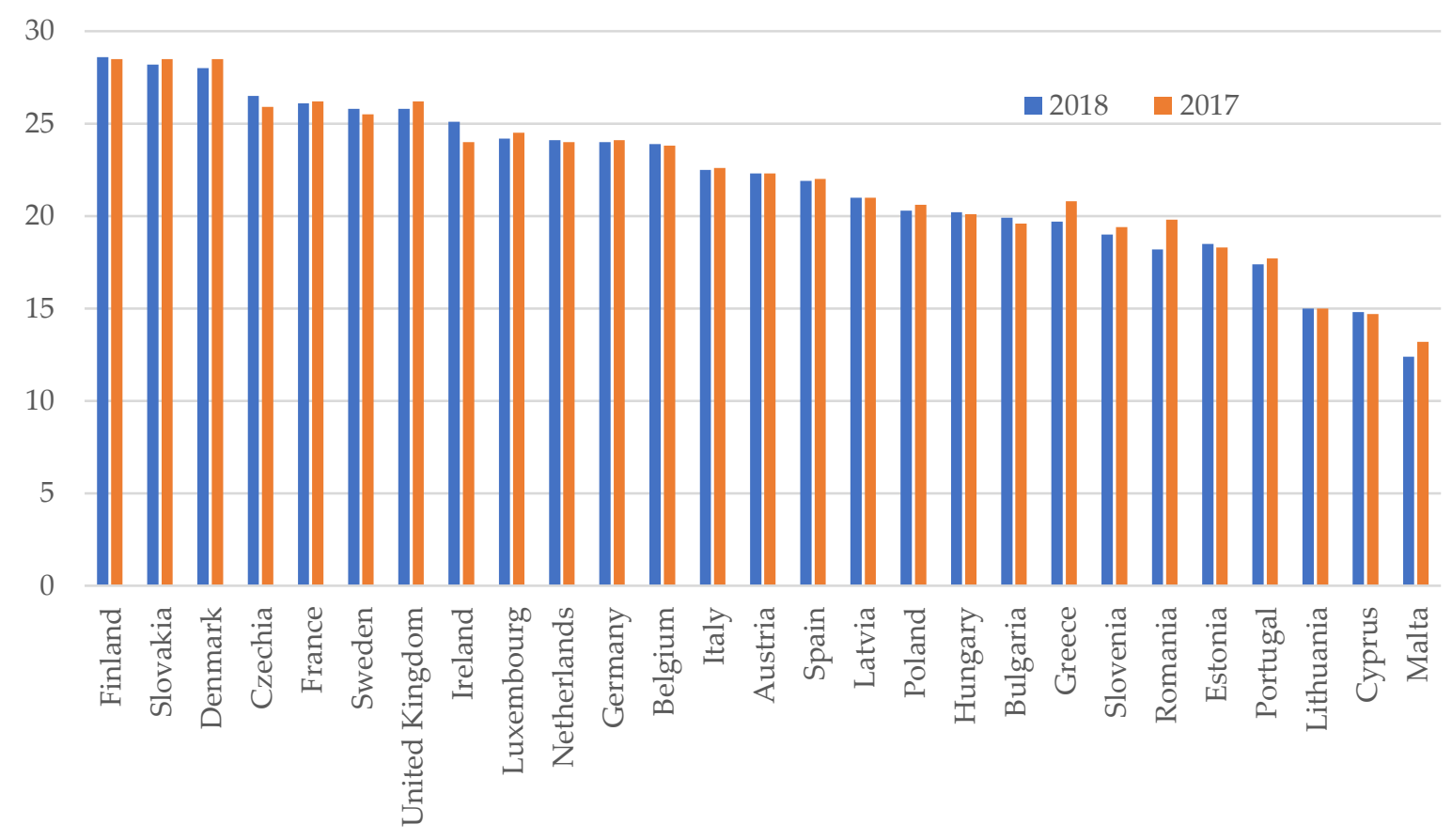

Figure 1. Share of housing, water, electricity, gas and other fuels in total household expenditure in the EU Member States in 2017-2018* (\%) (Eurostat, 2020e)

${ }^{*}$ Note: Croatia - data not available

Based on Figure 1, it can be concluded that the share of these expenses in the Czech Republic (25.9\% in 2017 and $26.5 \%$ in 2018) is higher than the average (24.1\% in 2017 and 23.9\% in 2018) in the European Union. Between 2017 and 2018, the share of "housing, water, electricity, gas and other fuels" in total household expenditure decreased or not changed in most Member States. In particular, the highest increase was recorded in Ireland (1.1 pp). In contrast, the share of "housing, water, electricity, gas and other fuels" in total household expenditure dropped in Romania (1.6 pp). In Poland it decreased by 0.3 percentage points (from $20.6 \%$ in 2017 to $20.3 \%$ in 2018). It is worth noting that the EU countries differ significantly not only in terms of the share of expenses related to house maintenance (including energy purchase costs), but also in terms of electricity consumption and prices (Figures 2 and 3).

The issues related to energy poverty are also associated with low energy efficiency of households (Tsanov and Shopov 2018). There is a need for modernization and erection of buildings that will meet the requirements for low energy demand. Energy poverty is a 


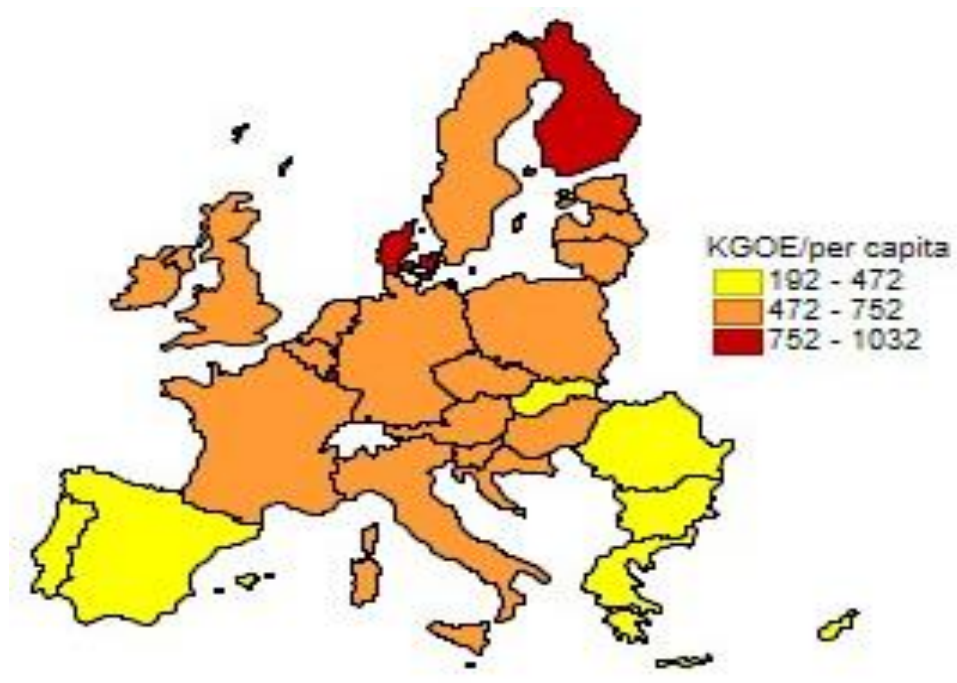

Figure 2. Final energy consumption in households per capita in EU-28 in 2018 (kg of oil equivalent/capita) (Eurostat, 2020b)

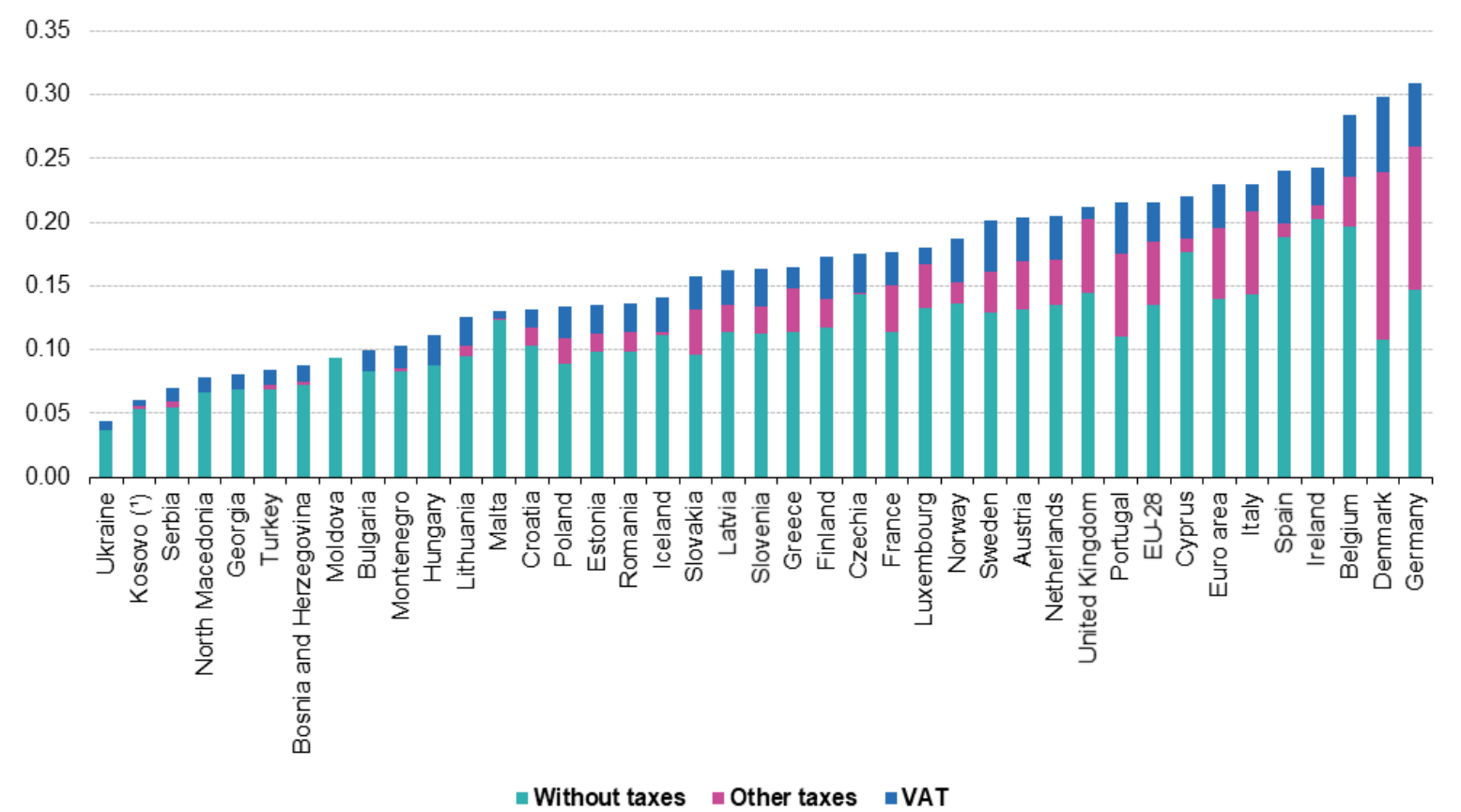

( ${ }^{1}$ This designation is without prejudice to positions on status, and is in line with UNSCR $1244 / 1999$ and the ICJ Opinion on the Kosovo Declaration of Independence.

Figure 3. Electricity prices for household consumers in EU-28, and other countries in Europe, first half 2019 (EUR per kWh) (Eurostat, 2020a)

structural problem that results, inter alia, from low standards in the area of energy-efficient buildings (Primc et al. 2019). This problem does not only concern the periods during which accommodation spaces must be heated. Climate change and, consequently, hotter summer months in this area of Europe are making intensive cooling of accommodation spaces necessary. This involves higher expenditures on electricity, which, given the high and still rising energy prices, may cause increased pressure in the area of energy poverty. Rural areas are particularly at risk of energy poverty (Aristondo \& Onaindia, 2018).

The basic indicator in the examined problem area is "Inability to keep home adequately warm - EU-SILC survey". This indicator is part of the EU Sustainable Development Goals 
(SDG) indicator set. It is used to monitor progress towards SDG 7 on affordable and clean energy and SDG 1 on ending poverty in all its forms everywhere (Eurostat, 2020c). Table 1 summarizes numerical data concerning the above subject matter in the EU-28 countries in the period of 2009-2018.

Table 1. Percentage of households in the EU-28 countries (with an income below $60 \%$ of the median income) declaring the inability to keep home adequately warm in 2009-2018 (Eurostat, 2020d)

\begin{tabular}{|c|c|c|c|c|c|c|c|c|c|c|}
\hline Specification & 2009 & 2010 & 2011 & 2012 & 2013 & 2014 & 2015 & 2016 & 2017 & 2018 \\
\hline Belgium & 5.1 & 5.6 & 7.1 & 6.6 & 5.8 & 5.4 & 5.2 & 4.8 & 5.7 & 5.2 \\
\hline Bulgaria & 64.2 & 66.5 & 46.3 & 46.5 & 44.9 & 40.5 & 39.2 & 39.2 & 36.5 & 33.7 \\
\hline Czechia & 5.2 & 5.2 & 6.4 & 6.7 & 6.2 & 6.1 & 5.0 & 3.8 & 3.1 & 2.7 \\
\hline Denmark & 1.5 & 1.9 & 2.3 & 2.5 & 3.8 & 2.9 & 3.6 & 2.7 & 2.7 & 3.0 \\
\hline Germany & 5.5 & 5.0 & 5.2 & 4.7 & 5.3 & 4.9 & 4.1 & 3.7 & 3.3 & 2.7 \\
\hline Estonia & 1.7 & 3.1 & 3.0 & 4.2 & 2.9 & 1.7 & 2.0 & 2.7 & 2.9 & 2.3 \\
\hline Ireland & 4.1 & 6.8 & 6.8 & 8.4 & 10.0 & 8.9 & 9.0 & 5.9 & 4.4 & 4.4 \\
\hline Greece & 15.7 & 15.4 & 18.6 & 26.1 & 29.5 & 32.9 & 29.2 & 29.1 & 25.7 & 22.7 \\
\hline Spain & 7.2 & 7.5 & 6.5 & 9.1 & 8.0 & 11.1 & 10.6 & 10.1 & 8.0 & 9.1 \\
\hline France & 5.5 & 5.7 & 6.0 & 6.0 & 6.6 & 5.9 & 5.5 & 5.0 & 4.9 & 5.0 \\
\hline Croatia & no data & 8.3 & 9.8 & 10.2 & 9.9 & 9.7 & 9.9 & 9.3 & 7.4 & 7.7 \\
\hline Italy & 10.8 & 11.6 & 17.8 & 21.3 & 18.8 & 18.0 & 17.0 & 16.1 & 15.2 & 14.1 \\
\hline Cyprus & 21.7 & 27.3 & 26.6 & 30.7 & 30.5 & 27.5 & 28.3 & 24.3 & 22.9 & 21.9 \\
\hline Latvia & 16.4 & 19.1 & 22.5 & 19.9 & 21.1 & 16.8 & 14.5 & 10.6 & 9.7 & 7.5 \\
\hline Lithuania & 24.1 & 25.2 & 36.2 & 34.1 & 29.2 & 26.5 & 31.1 & 29.3 & 28.9 & 27.9 \\
\hline Luxembourg & 0.3 & 0.5 & 0.9 & 0.6 & 1.6 & 0.6 & 0.9 & 1.7 & 1.9 & 2.1 \\
\hline Hungary & 8.9 & 10.7 & 12.2 & 15.0 & 14.6 & 11.6 & 9.6 & 9.2 & 6.8 & 6.1 \\
\hline Malta & 11.1 & 14.3 & 17.6 & 22.1 & 23.9 & 22.3 & 14.1 & 6.6 & 6.3 & 7.6 \\
\hline Netherlands & 1.3 & 2.3 & 1.6 & 2.2 & 2.9 & 2.6 & 2.9 & 2.6 & 2.4 & 2.2 \\
\hline Austria & 2.9 & 3.8 & 2.7 & 3.2 & 2.7 & 3.2 & 2.6 & 2.7 & 2.4 & 1.6 \\
\hline Poland & 16.3 & 14.8 & 13.6 & 13.2 & 11.4 & 9.0 & 7.5 & 7.1 & 6.0 & 5.1 \\
\hline Portugal & 28.5 & 30.1 & 26.8 & 27.0 & 27.9 & 28.3 & 23.8 & 22.5 & 20.4 & 19.4 \\
\hline Romania & 22.1 & 20.1 & 15.6 & 15.0 & 14.7 & 12.9 & 13.1 & 13.8 & 11.3 & 9.6 \\
\hline Slovenia & 4.6 & 4.7 & 5.4 & 6.1 & 4.9 & 5.6 & 5.6 & 4.8 & 3.9 & 3.3 \\
\hline Slovakia & 3.6 & 4.4 & 4.3 & 5.5 & 5.4 & 6.1 & 5.8 & 5.1 & 4.3 & 4.8 \\
\hline Finland & 1.3 & 1.4 & 1.8 & 1.5 & 1.2 & 1.5 & 1.7 & 1.7 & 2.0 & 1.7 \\
\hline Sweden & 1.7 & 2.1 & 1.9 & 1.7 & 0.9 & 1.1 & 1.2 & 2.6 & 2.1 & 2.3 \\
\hline United Kingdom & 5.8 & 6.1 & 6.5 & 8.1 & 10.6 & 9.4 & 7.8 & 6.1 & 5.9 & 5.4 \\
\hline EU - 28 countries & $9.3^{*}$ & 9.5 & 9.8 & 10.8 & 10.7 & 10.3 & 9.4 & 8.7 & 7.8 & 7.3 \\
\hline
\end{tabular}

Note: ${ }^{*}(27$ countries)

In 2018, a relatively high percentage of the population at risk of energy poverty (taking into account the analysed indicator) lived in Bulgaria (33.7\%) and Lithuania (27.9\%). In the analysed period, a distinct reduction in the percentage of the population declaring the inability to keep home adequately warm took place in: Bulgaria (by $30.5 \mathrm{pp}$ ); Romania (by $12.5 \mathrm{pp}$ ) and Poland (by $11.2 \mathrm{pp}$ ). The overall level of poverty in the analysed subjective and temporal scope decreased in the European Union countries by $2 \mathrm{pp}$ - from the level of $9.3 \%$ in 2009 to $7.3 \%$ in 2018. Against this background, the current level of the discussed indicator in Poland is favourable - in 2018 it was 5.1\%.

\section{Conclusions}

Apart from the problem of smog, energy poverty is one of the most important problems at the meeting point of the following areas: energy - efficiency - ecology - economy. The 
analyses show that the situation in Poland in terms of energy poverty, examined by the indicator selected in this study (Inability to keep home adequately warm - EU-SILC survey), improved significantly over the period of 2009-2018. In 2018, the value of the indicator in Poland was 5.1\%, while its average level in the EU was $7.3 \%$. The costs associated with the purchase of energy by households are important from the point of view of the considerations made in this study. At the beginning of January 2020, the Energy Regulatory Office in Poland approved tariffs for the sale of electricity to household consumers. According to the new tariffs, the price of electricity for individual consumers will increase in 2020 by 11.6 percent on average. Such a situation may result in difficulties in satisfying the energy needs of many households in Poland, and thus increase the scale of energy poverty. If the phenomenon of energy poverty is deepened, it can be expected that relatively poorer social groups will use fuels of lower quality to satisfy their basic energy needs. This means that the problem may also appear in the area of low-altitude emissions.

Acknowledgments: This study was conducted and financed in the framework of the research project "Socioeconomic, environmental and technical determinants of the energy poverty in rural areas in Poland", granted by the National Science Centre in Poland, program OPUS, grant No. 2018/31/B/HS4/00048.

\section{References}

Aristondo, O., \& Onaindia, E. (2018). Counting energy poverty in Spain between 2004 and 2015. Energy Policy, 113, 420-429. https://doi.org/10.1016/j.enpol.2017.11.027

Betto, F., Garengo, P., \& Lorenzoni, A. (2020). A new measure of Italian hidden energy poverty. Energy Policy, 138, 111237. https://doi.org/10.1016/j.enpol.2019.111237

Boemi, S. N., \& Papadopoulos, A. M. (2019). Monitoring energy poverty in Northern Greece: the energy poverty phenomenon. International Journal of Sustainable Energy, 38(1), 74-88. https://doi.org/10.1080/14786451.2017.1304939

Calì, D., Osterhage, T., Streblow, R., \& Müller, D. (2016). Energy performance gap in refurbished German dwellings: Lesson learned from a field test. Energy and Buildings, 127, 1146-1158. https://doi.org/10.1016/j.enbuild.2016.05.020

Castaño-Rosa, R., Solís-Guzmán, J., \& Marrero, M. (2020a). Energy poverty goes south? Understanding the costs of energy poverty with the index of vulnerable homes in Spain. Energy Research E Social Science, 60, 101325. https://doi.org/10.1016/j.erss.2019.101325

Castaño Rosa, R., Solís Guzmán, J., \& Marrero, M. (2020b). Midiendo la pobreza energética. Una revisión de indicadores. Revista Hábitat Sustentable, 10(1), 9-21. https://doi.org/10.22320/07190700.2020.10.01.01

Castaño-Rosa, R., Solís-Guzmán, J., Rubio-Bellido, C., \& Marrero, M. (2019). Towards a multiple-indicator approach to Energy Poverty in the European Union: A review. Energy and Buildings, 193, 36-48. https://doi.org/10.1016/j.enbuild.2019.03.039

Dobbins, A., Fuso Nerini, F., Deane, P., \& Pye, S. (2019). Strengthening the EU response to energy poverty. Nat Energy, 4(2-5). https://doi.org/10.1038/s41560-018-0316-8

Doukas, H., \& Marinakis, V. (2020). Energy poverty alleviation: effective policies, best practices and innovative schemes. Energy Sources, Part B: Economics, Planning, and Policy, 15, 45-58. https://doi.org/10.1080/15567249.2020.1756689

Druică, E., Goschin, Z., \& Ianole-Călin, R. (2019). Energy Poverty and Life Satisfaction: Structural Mechanisms and Their Implications. Energies, 12(20), 3988. https://doi.org/10.3390/en12203988

Eurostat. (2020a). Electricity prices for household consumer [Data set]. Retrieved January 25, 2021, from https://ec.europa.eu/eurostat/statisticsexplained/index.php?title=File:Electricity_prices_for_household_consumers,_first_half_2019_(EUR_per_k Wh)F1.png\&oldid=459599

Eurostat. (2020b). ESMS Indicator Profile [Data set]. Retrieved January 25, 2021, from https://ec.europa.eu/eurostat/databrowser/view/sdg_07_20/default/table?lang=en 
Eurostat. (2020c). Final energy consumption in households per capita [Data set]. Retrieved November 9, 2020, from https://ec.europa.eu/eurostat/tgm/table.do?tab=table\&plugin=1\&language=en\&pcode=sdg_07_20

Eurostat. (2020d). Inability to keep home adequately warm - EU-SILC survey [Data set]. Retrieved November 9, 2020, from https://ec.europa.eu/eurostat/web/products-datasets/product?code=ilc_mdes01

Eurostat. (2020e). Share of housing, water, electricity, gas and other fuels in total household expenditure [Data set]. Retrieved January 25, 2021, from http://appsso.eurostat.ec.europa.eu/nui

Gouveia, J. P., Seixas, J., \& Long, G. (2018). Mining households' energy data to disclose fuel poverty: Lessons for Southern Europe. Journal of Cleaner Production, 178, 534-550. https://doi.org/10.1016/j.jclepro.2018.01.021

Gupta, S., Gupta, E., \& Sarangi, G. K. (2020). Household Energy Poverty Index for India: An analysis of inter-state differences. Energy Policy, 144, 111592. https://doi.org/10.1016/j.enpol.2020.111592

Horta, A., Gouveia, J. P., Schmidt, L., Sousa, J. C., Palma, P., \& Simões, S. (2019). Energy poverty in Portugal: Combining vulnerability mapping with household interviews. Energy and Buildings, 203, 109423. https://doi.org/10.1016/j.enbuild.2019.109423

Khanna, R. A., Li, Y., Mhaisalkar, S., Kumar, M., \& Liang, L.J. (2019). Comprehensive energy poverty index: Measuring energy poverty and identifying micro-level solutions in South and Southeast Asia. Energy Policy, 132, 379-391. https://doi.org/10.1016/j.enpol.2019.05.034

Libor, G., \& Bouzarovski, S. (2018). The socio-demographic dimensions of energy poverty: a case study from Bytom, Poland. Urban Development Issues, 57(1), 63-77. https://doi.org/10.2478/udi-2018-0018

Mazurkiewicz, J., \& Lis, P. (2018). Diversification of energy poverty in Central and Eastern European countries. Virtual Economics, 1(1), 26-41. https://doi.org/10.34021/ve.2018.01.01(2)

Mędrzycki, R., \& Szyrski, M. (2018). Energy Poverty as a European Union and Polish Legal Issue. Białostockie Studia Prawnicze, 23(2), 125-138. https://doi.org/10.15290/bsp.2018.23.02.09

Meyer, S., Laurence, H., Bart, D., Middlemiss, L., \& Maréchal, K. (2018). Capturing the multifaceted nature of energy poverty: Lessons from Belgium. Energy Reesearch $\mathcal{E}$ Social Science, 40, 273-283. https://doi.org/10.1016/j.erss.2018.01.017

Monyei, C. G., Adewumi, A. O., Obolo, M. O., \& Sajou, B. (2018). Nigeria's energy poverty: Insights and implications for smart policies and framework towards a smart Nigeria electricity network. Renewable and Sustainable Energy Reviews, 81, 1582-1601. https://doi.org/10.1016/j.rser.2017.05.237

Olang, T. A., Esteban, M., \& Gasparatos, A. (2018). Lighting and cooking fuel choices of households in Kisumu City, Kenya: A multidimensional energy poverty perspective. Energy for Sustainable Development, 42, 1-13. https://doi.org/10.1016/j.esd.2017.09.006

Pablo, Q. S., Paloma, T. D. L. P., \& Francisco, J. T. (2019). Energy Poverty in Ecuador. Sustainability, 11(22), 6320. https://doi.org/10.3390/su11226320

Primc, K., \& Slabe-Erker, R. (2020). Social policy or energy policy? Time to reconsider energy poverty policies. Energy for Sustainable Development, 55, 32-36. https://doi.org/10.1016/j.esd.2020.01.001

Primc, K., Slabe-Erker, R., \& Majcen, B. (2019). Constructing energy poverty profiles for an effective energy policy. Energy Policy, 128, 727-734. https://doi.org/10.1016/j.enpol.2019.01.059

Romero, J. C., Linares, P., \& López, X. (2018). The policy implications of energy poverty indicators. Energy Policy, 115, 98-108. https://doi.org/10.1016/j.enpol.2017.12.054

Samarakoon, S. (2019). A justice and wellbeing centered framework for analysing energy poverty in the Global South. Ecological Economics, 165, 106385. https://doi.org/10.1016/j.ecolecon.2019.106385

Sareen, S., Thomson, H., Herrero, S. T., Gouveia, J. P., Lippert, I., \& Lis, A. (2020). European energy poverty metrics: Scales, prospects and limits. Global Transitions, 2, 26-36. https://doi.org/10.1016/j.glt.2020.01.003

Streimikiene, D., \& Balezentis, T. (2019). Innovative Policy Schemes to Promote Renovation of Multi-Flat Residential Buildings and Address the Problems of Energy Poverty of Aging Societies in Former Socialist Countries. Sustainability, 11(7), 2015. https://doi.org/10.3390/su11072015

Thomson, H., Bouzarovski, S., \& Snell, C. (2017). Rethinking the measurement of energy poverty in Europe: A critical analysis of indicators and data. Indoor and Built Environment, 26(7), 879-901. https://doi.org/10.1177/1420326X17699260

Tsanov, V., \& Shopov, G. (2018). Material standard of living and energy poverty in Bulgaria: state and development. Economic Studies, 27(6), 3-20.

Wei, Y. M., Liao, H., Wei, Y. M., \& Liao, H. (2018). The Interaction of Energy Poverty and Economic Development'. In Y.M. Wei, H. Liao (Eds.), Energy Economics: Understanding and Interpreting Energy Poverty in China (pp. 175193). Emerald Publishing Limited. 